\title{
Inventarisasi Penyakit pada Tanaman Jarak Pagar (Jatropha curcas L.) Pada Tiga Daerah di Jawa Barat
}

\author{
Krisna Dwi Laksono ${ }^{1}$, Ceppy Nasahi ${ }^{2}$ dan Nenet Susniahti ${ }^{2}$ \\ ${ }^{1}$ Alumni Jurusan Hama dan Penyakit Tumbuhan Fakultas Pertanian Universitas Padjadjaran \\ 2 Jurusan Hama dan Penyakit Tumbuhan Fakultas Pertanian \\ Universitas Padjadjaran \\ Jalan Raya Jatinangor Km. 21 Bandung 40600 \\ Korespondensi: ceppynasahi@gmail.com
}

\begin{abstract}
Inventory of Diseases on Physic nut (Jatropha curcas L.) in West Java Area.

Physic nut (Jatropha curcas L.) is an alternative source of oil-producing plants which could be developed in Indonesia. To ensure the growth and its production, all factors that influence the development of physic nut plant should be studied including plant disease. The objective of the research was to invent the diseases of Jatropha curcas belong to PT. Genting Oils in Bandung regency, PT. Rajawali Nusantara Indonesia (RNI) in Jatitujuh Majalengka, and PT. RNI in Purwadadi Subang in West Java. Survey method was carried out to observe diseases performance directly on sample plants. The result showed that powdery mildew caused by Oidium sp. with disease intensity of $38 \%$ was found in Cirata B plantation. Antracnose caused by Colletotrichum sp. was also found in Cirata A plantation with diseases intensity of $37 \%$. Sooty mold caused by Capnodium sp. attacked physic nut at Purwadadi and Jatitujuh plantation with disease intensity of $36 \%$ and $25.5 \%$ respectively. In addition, there were bacterial wilt caused by Pseudomonas sp., leaf blight gray caused by Pestalotiopsis sp., and reniform nematode (Rotylenchulus sp.) in all plantation.
\end{abstract}

Key words: Diseases, Diseases intensity, Physic nut.

\begin{abstract}
ABSTRAK
Tanaman jarak pagar (Jatropha curcas L.) adalah salah satu tanaman alternatif penghasil minyak nabati yang berpotensi untuk dikembangkan di Indonesia. Oleh karena itu, faktor-faktor yang mempengaruhi pengembangan jarak pagar perlu diperhatikan termasuk penyakit tanaman. Penelitian ini bertujuan untuk menginventarisasi penyakit tanaman yang terdapat di beberapa perkebunan jarak pagar di daerah Jawa Barat yaitu, PT. Genting Oils di Cirata Kabupaten Bandung, PT. Rajawali Nusantara Indonesia (RNI) di Jatitujuh Kabupaten Majalengka, dan PT. RNI di Purwadadi Kabupaten Subang. Metode yang digunakan dalam penelitian ini adalah metode survei dengan pengamatan keberadaan penyakit secara langsung pada tanaman sampel. Hasil pengamatan menunjukan bahwa penyakit embun tepung yang disebabkan oleh Oidium sp. dengan intensitas penyakit mencapai $38 \%$ ditemukan di kebun Cirata B. Penyakit antraknosa yang disebabkan oleh colletotrichum sp. dengan intesitas penyakit mencapai $37 \%$ ditemukan di kebun Cirata A. Penyakit embun jelaga yang disebabkan oleh Capnodium sp. terdapat di kebun Purwadadi dan Jatitujuh dengan intensitas penyakit mencapai masing-masing $36 \%$ dan 22,5\%. Selain itu, ditemukan juga penyakit layu bakteri yang disebabkan oleh Pseudomonas sp., penyakit hawar daun kelabu yang disebabkan oleh Pestalotiopsis sp., serta ditemukan juga keberadaan nematode Rotylenchulus sp. di seluruh area penelitian.
\end{abstract}

Kata kunci: Penyakit, Intensitas penyakit, Jarak Pagar. 


\section{PENDAHULUAN}

Krisis bahan bakar minyak mendorong Indonesia untuk mencari bahan bakar alternatif terbaru berbasis kekayaan biodiversitas tanaman. Menurut Hariyadi (2005), salah satu tanaman yang memiliki potensi sebagai sumber bahan bakar yang berbahan baku minyak nabati adalah tanaman jarak pagar (Jatropha cyrcas L.). Minyak nabati dari jarak pagar mudah terurai secara biologi, dapat mengurangi efek rumah kaca dengan mereduksi emisi gas $\mathrm{CO}_{2}$ dan dapat mengurangi polusi udara karena terbakar sempurna (Hambali, 2006; Sheenan et al. 1998).

Beberapa pemerintah daerah, Badan Usaha Milik Negara dan perusahaan swasta mulai menggalakkan penanaman jarak pagar. Pertamina melakukan penanaman seluas 2.700 ha di sekitar pabrik pengolahan minyak bumi PT Pertamina. PT. Rajawali Nusantara Indonesia (RNI) berencana menanam jarak seluas 1.100 ha, yaitu 350 ha di Cirebon, 150 ha di Subang, dan 600 ha di Pasuruan. PT. Genting, investor dari Malaysia, merencanakan penanaman jarak pagar seluas 40 ha di Cirata Kabupaten Bandung.

Secara argonomis, tanaman jarak pagar dapat beradaptasi dengan lahan maupun agroklimat di Indonesia. Namun budidaya tanaman jarak pagar menghadapi beberapa faktor pembatas termasuk Organisme Penggangu Tanaman (OPT). Keberadaan OPT pada tanaman jarak pagar dipengaruhi oleh faktor biotik dan abiotik seperti keadaan lingkungan sekitar serta teknik budidaya tanaman itu sendiri. Adanya OPT baik bakteri maupun jamur yang tidak dikendalikan dapat menurunkan produksi buah atau biji jarak pagar (Hambali 2006).

Informasi mengenai jenis-jenis penyakit tanaman jarak pagar sangat penting dalam menunjang pelaksanaan budidaya tanaman jarak pagar, terutama untuk menentukan teknik pengendalian OPT yang tepat. Agar budidaya tanaman jarak pagar dapat optimal, perlu diketahui penyakit-penyakit tanaman jarak pagar di lapangan. Akan tetapi, informasi tentang penyakit tanaman jarak pagar masih sangat terbatas khususnya di daerah Jawa Barat. Oleh karena itu, penelitian ini dilakukan untuk menginventarisasi jenis-jenis penyakit yang menyerang serta menentukan intensitas penyakitnya di beberapa lokasi perkebunan jarak pagar di Jawa Barat.

\section{BAHAN DAN METODE}

Pengambilan sampel tanaman dilakukan di tiga perkebunan jarak pagar, yaitu di kebun jarak pagar milik PT. Genting Oils di Cirata, Kabupaten Bandung ( $\pm 325 \mathrm{~m} \mathrm{dpl);} \mathrm{kebun} \mathrm{jarak} \mathrm{pagar} \mathrm{milik} \mathrm{PT.}$ RNI di Jatitujuh, Kabupaten Majalengka ( $\pm 50 \mathrm{~m}$ dpl); dan kebun jarak pagar milik PT. RNI di Purwadadi, Kabupaten Subang ( $\pm 30 \mathrm{~m} \mathrm{dpl}$ ). Metode yang digunakan dalam penelitian ini adalah metode survey dengan pengamatan dilakukan secara langsung pada tanaman sampel. Identifikasi bakteri penyebab penyakit dilakukan di Laboratorium Mikrobiologi, Sekolah Ilmu Teknologi Hayati, Institut Teknologi Bandung. Identifikasi jamur dan nematoda penyebab penyakit masing-masing dilakukan di Laboratorium Fitopatologi dan Laboratorium Nematologi, Jurusan Hama dan Penyakit Tumbuhan, Fakultas Pertanian, Universitas Padjadjaran. Penelitian dilakukan pada musim kemarau dari bulan Agustus 2008 sampai November 2008.

\section{Penentuan Petak Sampel dan Tanaman Sampel}

Di setiap kebun jarak pagar, tanaman sampel diambil dari lima petak sampel yang ditentukan secara diagonal menurut Cambell \& Madden (1990). Dalam setiap petak sampel terdapat 10 tanaman sehingga di setiap lahan diamati 50 tanaman sampel. Sampel tanah sebanyak $500 \mathrm{~g}$ diambil dari daerah perakaran tanaman yang memperlihatkan gejala sakit. Luas masing-masing lahan percobaan yang digunakan adalah sekitar $600 \mathrm{~m}^{2}$.

\section{Identifikasi Penyebab Penyakit}

Pengamatan tanaman yang terserang penyakit dilakukan pada sampel akar, batang, daun, dan buah yang sakit. Bakteri patogen di bagian tanaman yang sakit dengan gejala serangan bakteri diisolasi dengan media Nutrient Agar. Identifikasi bakteri dilakukan secara biokimia mengacu kepada Bergey's Manual Determinative Bacteriology (Holt et al. 1993). Jamur patogen dari bagian tanaman yang diduga terserang penyakit oleh jamur diisolasi dengan media Potato Dextrose Agar. Identifikasi jamur dilakukan berdasarkan ciri morfologi badan vegetatif dan generatif menurut Barnett \& Hunter (1972). Sampel tanah diekstraksi dengan Metode Corong Baermann untuk mengetahui populasi nematoda. Identifikasi nematoda dilakukan secara morfologi sesuai dengan penjelasan Luck et al. (2005). 


\section{Penghitungan Intensitas Penyakit}

Penghitungan intensitas penyakit dilakukan dengan dilakukan dengan beberapa cara tergantung sifat infeksinya. Intensitas penyakit dihitung sebagai persentase tanaman terserang (disease incidence) atau intensitas penyakit (disease severity). Perhitungan persentase tanaman terserang dilakukan jika infeksi penyebab penyakit terjadi secara sistematik sehingga gejala internalnya mungkin sudah menyebar ke seluruh bagian tanaman walaupun gejala yang eksternal terlihat hanya sedikit. Persentase tanaman terinfeksi berdasarkan rumus :

$\%$ tanaman terinfeksi $=\frac{\text { Jumlah tanaman yang terinfeks }}{\text { Jumlah tanaman sampel }} \times 100 \%$

Intensitas penyakit ditentukan dengan rumus Horsfall \& Barratt (1997) yaitu :

$$
\mathrm{I}=\frac{\Sigma(\mathrm{ni} \times \mathrm{vi})}{\mathrm{N} \times \mathrm{V}} \times 100 \%
$$

dimana:

I : Intensitas penyakit

ni : Banyak tanaman yang diamati dengan skor ke-i

vi : Skor tanaman ke-i

$\mathrm{N}$ : Total tanaman yang diamati

$\mathrm{V}$ : Skor serangan tertinggi

Persentase kerusakan yang ditentukan berdasarkan nilai skoring gejala dikategorikan ke dalam tidak ada serangan, serangan ringan, sedang, agak berat dan berat

\section{HASIL DAN PEMBAHASAN}

\section{Penyakit Tanaman Jarak Pagar}

Berdasarkan pengamatan di lapangan terdapat enam penyakit yang menyerang tanaman jarak pagar di daerah Jawa Barat (Tabel 1).

Observasi penyakit di PT. Genting Oils (Cirata) dilakukan di dua area yaitu kebun Cirata A dan B yang terpisah oleh jalan. Ketinggian tempat kebun Cirata A lebih rendah daripada Cirata B.

\section{Embun Tepung}

Penyakit ini menyerang jarak pagar di kebun Cirata A dan Cirata B. Pada beberapa bagian permukaan daun dan batang terdapat bercak putih kelabu (Gambar 1) seperti beludru halus yang menurut Semangun (2000) disebabkan oleh Oidium sp. Berdasarkan pengamatan di lapangan, gejala lanjut penyakit berupa tepung putih yang meluas hampir menutupi seluruh bagian permukaan daun. Gejala ini mengakibatkan warna daun kusam kecoklatan dan jaringan tanaman menjadi klorosis sehingga proses fisiologis terganggu sehingga daun kering dan gugur (Semangun, 2000).

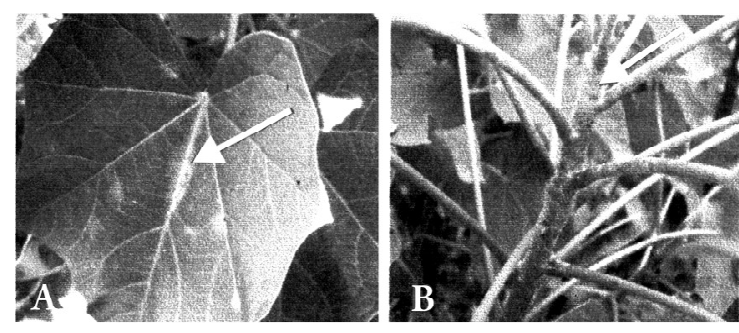

Gambar 1. Gejala penyakit embun tepung pada daun (A) dan batang (B)

Tabel 1. Penyakit tanaman jarak pagar di beberapa area perkebunan di Jawa Barat

\begin{tabular}{|c|c|c|c|c|}
\hline \multirow{2}{*}{ Penyakit } & \multicolumn{4}{|c|}{ Kebun } \\
\hline & Cirata A & Cirata B & Jatitujuh & Purwadadi \\
\hline $\begin{array}{l}\text { Embun Tepung } \\
\text { (Oidium sp.) }\end{array}$ & $\sqrt{ }$ & $\sqrt{ }^{*}$ & - & - \\
\hline $\begin{array}{l}\text { Embun Jelaga } \\
\text { (Capnodium sp.) }\end{array}$ & - & $\sqrt{ }$ & $\sqrt{ }^{*}$ & $\sqrt{*}$ \\
\hline $\begin{array}{l}\text { Antraknosa } \\
\text { (Collectotrichum sp.) }\end{array}$ & $\sqrt{ }^{*}$ & $\sqrt{ }$ & - & - \\
\hline $\begin{array}{l}\text { Hawar Daun Kelabu } \\
\text { (Pestalotiopsis sp.) }\end{array}$ & - & - & $\sqrt{ }$ & $\sqrt{ }$ \\
\hline $\begin{array}{l}\text { Layu bakteri } \\
\text { (Ralstonia solanacearum) }\end{array}$ & $\sqrt{ }$ & - & $\sqrt{ }$ & $\sqrt{ }$ \\
\hline $\begin{array}{l}\text { Nematoda } \\
\text { (Rotylenchulus sp.) }\end{array}$ & $\sqrt{ }$ & $\sqrt{ }$ & - & - \\
\hline
\end{tabular}

Keterangan: $\sqrt{ }=$ Keberadaan penyakit, ${ }^{*}=$ Dominan pada kebun tersebut 
Hasil pengamatan mikroskopis ditemukan konidia jamur hialin, tidak bersekat, yang tersusun seperti rantai melekat pada konidiofornya (Gambar 2). Menurut Barnett \& Hunter (1972), konidia jamur dengan ciri tersebut adalah konidia jamur Oidium $s p$.

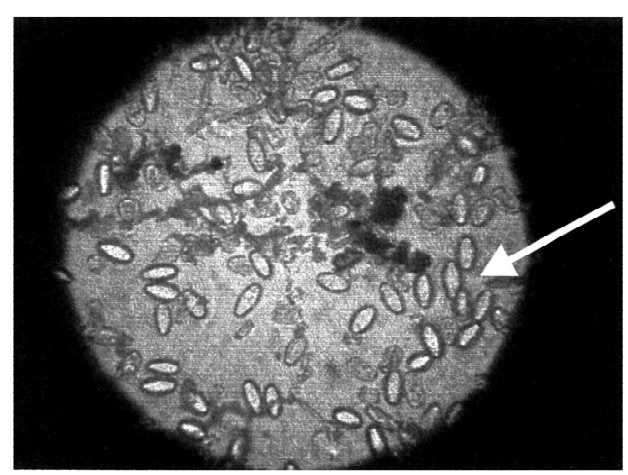

Gambar 2. Konidia jamur Oidium sp.

Kondisi lingkungan di kebun Cirata B mendukung timbulnya penyakit embun tepung karena suhu di kebun adalah $22{ }^{\circ} \mathrm{C}-28{ }^{\circ} \mathrm{C}$ dengan area agak ternaungi oleh pohon besar sehingga kurang sinar matahari. Semangun (2000) menyatakan bahwa terjadinya penyakit embun tepung terinduksi oleh intensitas sinar matahari rendah dan intensitas hujan rendah pada suhu $23^{\circ} \mathrm{C}$ - $25^{\circ} \mathrm{C}$. Kebun Cirata B juga sudah menjadi daerah endemik penyakit embun tepung karena sebelumnya area ini adalah perkebunan karet.

Di kebun Jatitujuh dan kebun Purwadadi tidak ditemukan gejala penyakit embun tepung. Kebun Jatitujuh dan Puwadadi sangat terbuka tidak ada naungan pohon sehingga tanaman disinari matahari langsung. Selain itu juga kebun jarak di Jatitujuh dan Purwodadi terletak di dataran rendah. Menurut Semangun (2007) penyakit embun tepung jarang terjadi di dataran rendah.

\section{Embun Jelaga}

Penyakit embun jelaga ditemukan di kebun Cirata B, Jatitujuh dan Purwadadi tetapi dominan di kebun Jatitujuh dan Purwadadi. Pada permukaan daun dan batang terdapat lapisan hitam merata yang mudah dikelupas dari daun (Gambar 3) tetapi jaringan daun di bawahnya tetap hijau.

Adanya gejala yang membentuk lapisan hitam merata pada permukaan daun disebabkan oleh jamur saprofit dari genus Capnodium. Jamur hanya menutupi permukaan daun tetapi tetap merugikan karena menghambat metabolisme daun terutama fotosintesis. Efeknya merambat ke pembentukan bunga/buah yang tidak normal sehingga tanaman tidak berproduksi maksimal (Semangun, 2007). Hasil pengamatan mikroskopis ditemukan jamur Capnodium sp. yang dicirikan dengan badan buah jamur yang berupa pseudotehium, berwarna hitam, berbentuk bulat memanjang (Gambar 4).

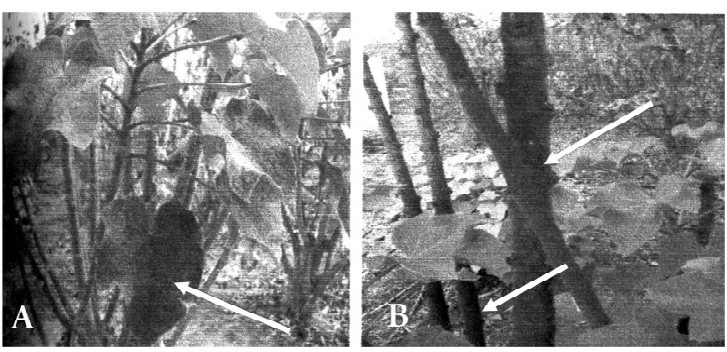

Gambar 3. Gejala penyakit embun jelaga pada daun (A) dan batang (B)

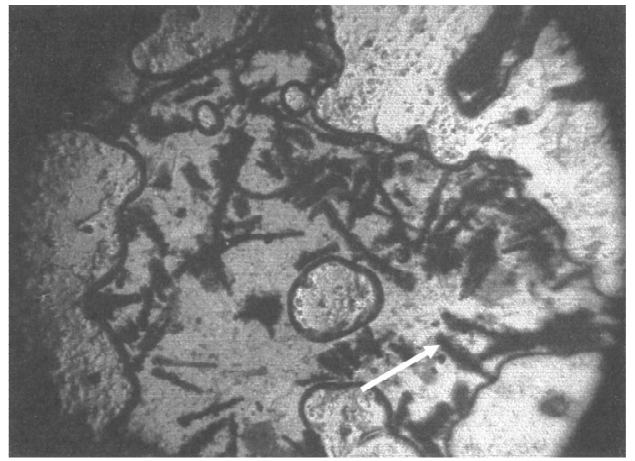

Gambar 4. Pseudotehium jamur Capnodium sp.

Di kebun Jatitujuh dan Purwadadi serangan jamur Capnodium sp. berkaitan dengan populasi hama kutu putih. Suhu di kebun Jatitujuh adalah 25,5 ${ }^{\circ} \mathrm{C}-29,1{ }^{\circ} \mathrm{C}$ sedangkan di kebun Purwadadi adalah 20,3 ${ }^{\circ} \mathrm{C}-32,8{ }^{\circ} \mathrm{C}$. Musim kemarau yang panas dapat mendukung perkembangan kutu putih sehingga populasinya terus meningkat.

\section{Antraknosa}

Penyakit antraknosa terdapat di kebun Cirata A dan Cirata B, tidak ditemukan di kebun Jatitujuh maupun Purwadadi. Penyakit ini dominan di kebun Cirata A. Pada permukaan daun terdapat bercakbercak bulat berwarna cokelat kehitaman yang dibatasi halo berwarna kuning (gambar 5A dan 5B). Gejala lanjut penyakit ini adalah bercak bulat meluas, daun mengering dan berlubang di tengahnya. Penyakit yang menginfeksi daun muda menyebabkan daun mati kemudian gugur. Menurut Yulianti et al., (2007), gejala-gejala penyakit pada daun jarak pagar yang berupa bercak hitam bulat 
dibatasi oleh halo berwarna kuning disebabkan oleh jamur Colletotrichum sp. Berdasarkan pengamatan mikroskopis ditemukan konidia jamur berbentuk bulat agak lonjong, tidak bersekat dan hialin (Gambar 6) yang menurut Barnett \& Hunter (1972) adalah konidia jamur Colletotrichum sp.

Penyakit ini sudah endemik di daerah perkebunan jarak pagar di Cirata A. Sejarah lahan sebelumnya di sekitar lingkungan kebun ini pernah digunakan sebagai lahan tanaman buah dan perkebunan karet yang merupakan tanaman inang jamur Colletotrichum sp. Suhu di sekitar kebun Cirata A yang berkisar $22{ }^{\circ} \mathrm{C}-28{ }^{\circ} \mathrm{C}$ juga mendukung perkembangan penyakit ini. Menurut Semangun (2000) penyakit antraknosa dapat berkembang dengan baik pada suhu $25^{\circ} \mathrm{C}-28^{\circ} \mathrm{C}$.
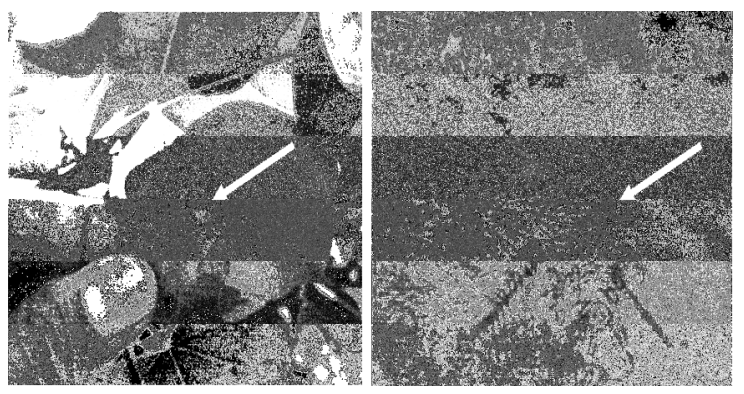

Gambar 5. Gejala penyakit antraknosa (A) dan konidia jamur Colletotrichum sp.

\section{Layu Bakteri}

Penyakit ini ditemukan di kebun Cirata A, Jatitujuh, dan Purwadadi dengan intensitas penyakit yang sangat rendah tetapi tidak ditemukan di kebun Cirata B. Rendahnya intensitas penyakit dan tidak ditemukannya penyakit pada kebun lainnya karena dilakukan pengendalian preventif dengan segera mencabut tanaman yang memperlihatkan gejala penyakit.

Tanaman memperlihatkan gejala daun layu terutama di bagian bawah (Gambar 6). Gejala ini akan menyebabkan daun layu menjadi kering, rontok dan akhirnya tanaman mati. Perakaran dan pangkal batang tanaman menjadi lebih lunak dan tampak busuk basah. Ketika pangkal batang atau akar dipotong melintang kemudian dimasukan ke dalam air akan terlihat cairan kental berwarna keruh kekuningan yang keluar dari bagian tersebut. Cairan kental tersebut diduga adalah massa bakteri dari dalam batang.

Hasil identifikasi mikroskopis menunjukan bahwa penyebab penyakit tersebut adalah bakteri Pseudomonas sp. berbentuk batang, gram negatif dengan warna koloni keruh kekuningan. Pengamatan makroskpis juga memperlihatkan bahwa penyakit dengan ciri gejala tersebut disebabkan oleh Pseudomonas sp.

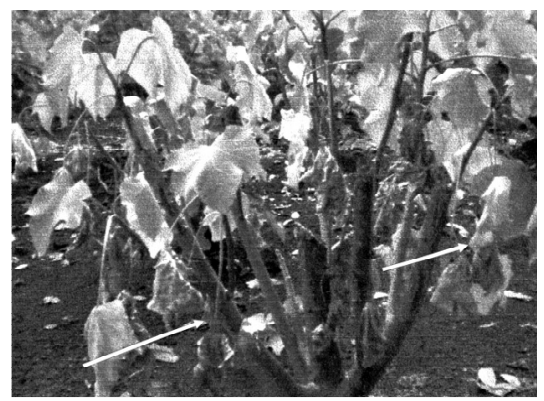

Gambar 6. Tanaman jarak pagar dengan gejala penyakit layu bakteri

\section{Hawar Daun Kelabu}

Penyakit hawar daun kelabu ini ditemukan pada kebun Jatitujuh dan Purwadadi dengan intensitas penyakit yang sangat rendah. Pada permukaan daun terdapat hawar berwarna cokelat yang tidak beraturan. Lama kelamaan hawar daun membesar dengan bagian tengah mengering berwarna cokelat dan sedikit abu-abu. Hawar yang sudah sangat mengering kemudian sobek (Gambar 7). Menurut Semangun (2000), gejala hawar kecil berwarna cokelat pada permukaan daun yang dapat membesar sehingga pusatnya mengering berwarna cokelat muda atau kelabu disebabkan oleh jamur Pestaloptiopsis sp. Dari pengamatan mikroskopis ditemukan konida jamur berbentuk kumparan yang terdiri atas beberapa sekat, dan hialin. Menurut Barnett \& Hunter (1972), ciri konida seperti ini adalah jamur Pestaloptiopsis sp.
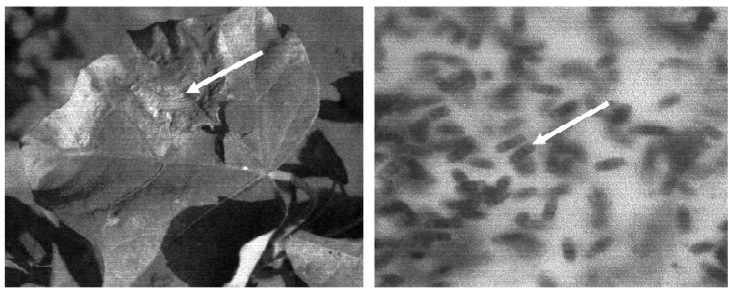

Gambar 7. Gejala penyakit hawar daun kelabu pada daun jarak pagar (kiri) dan. Konidia jamur Pestaloptiopsis sp (kanan)

Keadaan kebun Jatitujuh dan Purwadadi kurang baik karena tanah kering serta kekurangan air dan unsur hara sehingga tanaman lebih rentan terhadap penyakit ini (Semangun, 2000). Keberadaan populasi serangga hama di kebun juga ikut 
membantu terjadinya infeksi penyakit. Jamur memasuki tanaman melalui luka pada daun yang diakibatkan oleh serangan hama. Di kebun Cirata A dan Cirata B tidak ditemukan penyakit ini, keadaan kebun cukup baik karena tanah agak lembab dan dilakukan pemupukan.

\section{Nematoda}

Di kebun jarak pagar terlihat ada tanaman kerdil dan tidak tumbuh normal. Di dalam tanah ditemukan nematoda dengan ukuran tubuh pendek, kutikula halus, bagian ujung tubuh runcing, stilet pendek, knob bulat, esophagus tidak jelas, dan vulva terletak di bagian belakang (posterior) tubuh. Menurut Eisenback (2002), nematoda dengan ciri tersebut adalah nematoda dari genus Rotylenchulus.

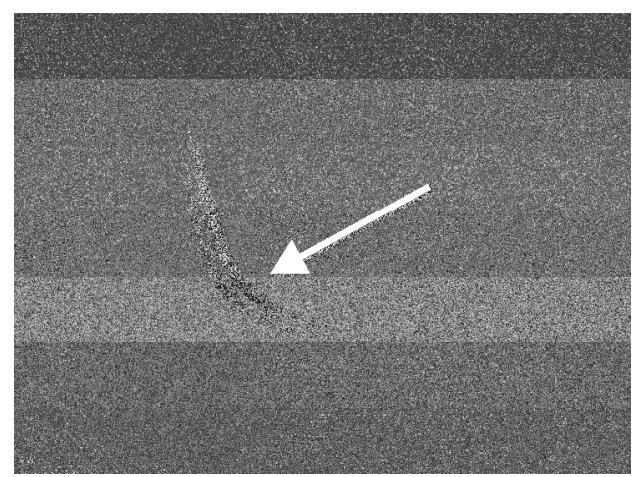

Gambar 8. Nematoda Rotylenchulus sp. yang diisolasi dari tanah di sekitar perakaran jarak pagar dengan gejala penyakit

Nematoda ini ditemukan di kebun Cirata A dan Cirata B, dengan populasi yang tidak terlalu banyak yaitu sekitar 39 larva $100 \mathrm{mg}^{-1}$ di kebun Cirata A dan 24 larva $100 \mathrm{mg}^{-1}$ di kebun Cirata B. Di kebun Jatitujuh dan Purwadadi tidak ditemukan nematoda ini karena tanah di kebun Jatitujuh dan Purwadadi sangat kering serta panas, sehingga nematoda tidak dapat hidup.

\section{Intensitas Penyakit}

Intensitas penyakit yang dihitung pada setiap kebun hanya penyakit yang dominan (gejala penyakit paling banyak ditemukan dibanding penyakit lain) pada kebun tersebut. Penyakit lain yang ditemukan tetapi tidak dihitung intensitas penyakitnya. Di kebun Cirata B penyakit yang dominan adalah embun tepung dengan intensitas mencapai $38 \%$. Penyakit yang dominan di kebun Jatitujuh dan Purwadadi adalah embun jelaga dengan intensitas masing-masing 22,5 \% dan $36 \%$ sedangkan di kebun Cirata A adalah Antraknosa dengan intensitas $37 \%$.

Secara umum, setiap minggu intensitas setiap penyakit meningkat (Gambar 9). Intensitas panyakit di sekitar area pertanaman dipengaruhi oleh faktor lingkungan di sekitar area pertanaman tersebut yang mendukung penyakit untuk berkembang. Selain itu suhu dan kelembaban di sekitar area pertanaman juga dapat mempengaruhi perkembangan penyakit (Agrios, 1997).

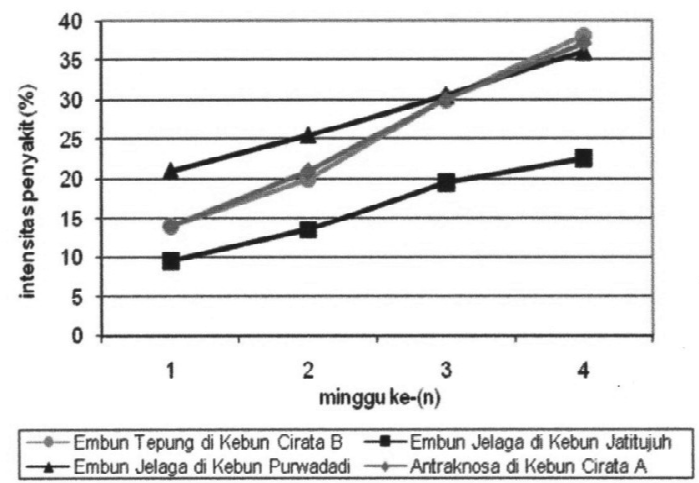

Gambar 9. Peningkatan intensitas penyakit tanaman jarak pagar di beberapa perkebunan jarak pagar di Jawa Barat

\section{Embun Tepung}

Intensitas penyakit embun tepung di kebun Cirata B mencapai $38 \%$. Perkembangan penyakit embun tepung pada kebun Cirata B dipengaruhi oleh adanya naungan oleh pohon besar dan angin yang bertiup melalui pohon sehingga patogen mudah menyebar (Semangun, 2000). Jarak tanam yang rapat yaitu 1,5 $\mathrm{m} \times 1,5 \mathrm{~m}$, menyebabkan kelembaban tinggi dan suhu rendah sehingga patogen akan berkembang

\section{Embun Jelaga}

Intensitas penyakit embun jelaga di kebun Jatitujuh mencapai 22,5 \% dan di kebun Purwadadi mencapai $36 \%$. Keberadaan kutu putih di kebun Jatitujuh dan Purwadadi adalah salah satu penyebab infenstasi Capnodium sp. kutu putih mengeluarkan cairan embun madu untuk mendukung perkembangan Capnodium sp. (Semangun, 2007). Kurangnya intensitas pengendalian hama di kedua kebun mendukung meningkatnya populasi kutu putih. Penyebaran jamur ini dibantu oleh angin. Jarak tanam yang cukup rapat yaitu 1,5 $\mathrm{m} \times 1,5 \mathrm{~m}$, dapat mempermudah patogen untuk menyebar dengan cara kontak dari tanaman yang sakit ke tanaman yang sehat. 
Penyakit embun jelaga tidak ditemukan di kebun Cirata A karena secara visual populasi kutu putih rendah. Pengendalian kimia dengan insektisida dan juga pengendalian mekanis yang dilakukan di kebun Cirata A mampu menekan populasi kutu putih sehingga pertumbuhan Capnodium sp. terkendali.

\section{Antraknosa}

Intensitas penyakit antraknosa di kebun Cirata A mencapai 37 \%. Kondisi lingkungan kebun yang agak rimbun ternaungi oleh pohon besar dan banyaknya angin mendukung perkembangan penyakit ini. Jarak tanam pada kebun Cirata A juga cukup rapat disertai angin menyebabkan kontak intensif antara tanaman sehat tanaman sakit.

Inventarisasi penyakit jarak pagar ini akan berkontribusi terhadap optimasi budidaya jarak pagar untuk bahan baku bahan bakar minyak nabati karena di berbagai negara dilaporkan OPT menimbulkan kerusakan merugikan (Prihandana \& Hendroko, 2006). Serangan penyakit akibat virus dengan intensitas $50 \%$ telah dilaporkan oleh Narayana et al. (2006) di kebun jarak pagar India. Tanaman jarak pagar dengan gejala serangan virus juga telah ditemukan di Jawa Barat (Jati et al., 2009). Karmawati \& Sukamto (2008) telah mengidentifikasi keberadaan penyakit Jarak pagar yang disebabkan oleh Ralstonia solanacearum di kebun jarak pagar di Cikarang. Di provinsi Lampung juga telah dilaporkan adanya bercak daun Cercospora dan Alternaria serta layu bakteri dan layu Fusarium di pertanaman jarak pagar (Ginting \& Maryono, 2009). Pada awal tahun 2009, untuk pertama kali Lasiodiplodia theobromae berhasil diisolasi secara konsisten dari tanaman jarak pagar terserang penyakit di India (Latha et al., 2009).

Hasil penelitian ini melengkapi penemuanpenemuan di atas. Dengan demikian inventarisasi penyakit jarak pagar menjadi lebih lengkap sehingga metode pencegahan dan pengendalian penyakit jarak pagar akan dapat ditentukan dengan lebih baik.

\section{SIMPULAN}

Penyakit yang ditemukan di beberapa area perkebunan jarak pagar di daerah Jawa Barat antara lain embun tepung yang disebabkan oleh Oidium sp., embun jelaga yang disebabkan oleh Colletotrichum sp., hawar daun kelabu yang disebabkan oleh Pseudomonas sp., hawar daun kelabu yang disebabkan oleh Pestalotiopsis sp., dan penyakit karena nematoda Rotylenchulus sp.
Penyakit dengan intensitas tertinggi di kebun Cirata A adalah antraknosa dengan intensitas $37 \%$, di kebun Cirata B adalah embun tepung dengan intensitas $38 \%$, di kebun Jatitujuh dan Purwadadi adalah embun jelaga dengan intensitas masing-masing 22,5 \% dan 36\%. Nematoda Rotylenchulus sp. ditemukan di kebun Cirata A dan Cirata B.

\section{SARAN}

Inventarisasi penyakit pada tanaman jarak pagar dilakukan pada musim kemarau sehingga masih perlu dilakukan penelitian di musim yang berbeda (hujan). Selain itu juga masih perlu dilakukan inventarisasi penyakit jarak pagar di lokasi yang berbeda pada musim yang sama.

\section{DAFTAR PUSTAKA}

Barnett, HI and BB Hunter. 1972. Illustrated Genera of Imperfect Fungi. Third Edition, Burgeus Publishing Company, New York. 218 pp.

Ginting, C dan T. Maryono. 2009. Physic nut (Jatropa curcas) diseases in Lampung province. Biotrophia 16 (44-53).

Hambali, E. 2006. Jarak Pagar Tanaman Penghasil Biodiesel. Swadaya, Jakarta. 131 hal.

Hariyadi, 2005. Budidaya tanaman jarak (Jatropha curcas) sebagai sumber bahan alternatif biofuel. Makalah disampaikan pada Focus Group Discussion Prospektif Sumberdaya Lokal Energi. Kementrian Riset dan Teknologi. Serpong, 14-15 September 2005. www.ristek.go.id. Diakses 28 Mei 2008

Holt. E. 1993. Bergey's Manual of Determinative Bacteriology. 9th ed. Baltimore: Williams \& Wilkins.

Jati, MF, C Nasahi dan D Suwantapura. 2009. Deteksi keberadaan virus pada tanaman jarak pagar (Jatropha curcas L.) dengan gejala infeksi virus melalui metode hayati dan Enzyme-linked innuno-sorbent assay. J. Agrikultura. 20:143-147.

Karmawati, E dan Sukamto (2008). Control of physic nut bacterial diseases using antagonic microbia.

http://balittas.litbang.deptan.go.id/eng/imag es/jarpag4/hama/Elna\%20Karmawati\%201_ \%20dan\%20Sukamto2_.pdf.6. Diakses 6 Desember 2009 
Latha, P, V Prakasam, A Kamalakannan, C Gopalakrishnan, T. Raguchander, M Paramathma and R. Samiyappan. 2009. First report of Lasiodiplodia theobromae (Pat.) Griffon \& Maubl causing root rot and collar rot disease of physic nut (Jatropha curcas L.) in India. Australasian Plant Disease Notes 4:19-20

Luc M, Sikora RA, Bridge J. 2005. Plant Parasitic Nematodes in Subtropical and Tropical Agricultural. $\quad$ Ed ke-2. USA: CABI Publishing.

Prihandana, R dan R Hendroko. 2006. Petunjuk Budidaya Jarak Pagar. PT Agromedia Pustaka, Jakarta. 79 hal.
Semangun, H. 2000. Pengantar Ilmu Penyakit Tanaman Perkebunan di Indonesia. Gajah Mada University Press, Yogyakarta.

Sheenan, J, V Camobreco, J Duffield, M Graboski and H Shapouri. 1998. An Overview of Biodiesel and Petroleum Diesel Lufe Cycles. American solar energy society inc. Colorado. 48 pp.

Yulianti, T, N Hidayah dan C Suhara. 2007. Penyakit tanaman jarak pagar (Jatropha curcas L.). Prosiding Lokakarya Teknologi Tanaman Jarak Pagar, Bogor 29 November 2006. Hal 91-96 